Artigos 


\title{
Ordem e tradição: \\ a conversão regionalista de \\ José Lins do Rego
}

\author{
César Braga-Pinto ${ }^{1}$ e 2
}

\section{Resumo}

O ensaio faz um esboço da biografia intelectual do jovem José Lins do Rego durante os anos 1919-1924, considerando-se o contexto cultural e sociopolítico da época. De particular interesse é seu encontro com Gilberto Freyre e o impacto do diálogo estabelecido com o amigo pernambucano em sua obra. Destacam-se nos primeiros escritos de ambos os autores certas afinidades, inclusive com o grupo de católicos e espiritualistas do Rio de Janeiro, particularmente com Jackson de Figueiredo. Apesar das ambiguidades e contradições dos seus autores, a defesa da ordem e da tradição permanece na base do projeto regionalista que se firmaria durante a década de 1930.

\section{Palavras-chaves}

José Lins do Rego, Gilberto Freyre, Jackson de Figueiredo, regionalismo, literatura católica.

Recebido em 3 de novembro de 2010

Aprovado em 27 de janeiro de 2011

1 Associate professor de Literatura Brasileira e Comparada, Northwestern University. E-mail: c-braga-pinto@northwestern.edu

2 Este artigo não teria sido possível sem a colaboração generosa do professor Anco Márcio Tenório; dos funcionários das seguintes instituições: Arquivo Público Estadual de Pernambuco, Biblioteca Pública de Pernambuco, Fundação Joaquim Nabuco, Arquivo Público de Alagoas, Biblioteca Nacional do Rio de Janeiro e Museu José Lins do Rego. Agradeço também o apoio do professor Antônio Dimas durante meu pós-doutorado na USP em 2006-2007. 


\section{Order and tradition: José Lins do Rego's regionalist conversion}

\section{César Braga-Pinto}

\section{Abstract}

This essay outlines the intellectual biography of the young José Lins do Rego during the years 1919-1924, considering the cultural, social and political contexts of the period. Of particular interest is his encounter with Gilberto Freyre and the impact that the dialogue which he established with his new friend from Pernambuco had in his work. The essay focuses on some of their early writings and indicates certain affinities, particularly with the group of Catholics and spiritualists from Rio de Janeiro and above all the figure of Jackson de Figueiredo. Their defense of order and tradition in the early 1920's constitutes one of the elements on the basis of the traditionalist regionalism that would be practiced during the 1930's.

\section{Keywords}

José Lins do Rego, Gilberto Freyre, Jackson de Figueiredo, regionalism, Catholicism in literature. 
No segundo ano, porém, conhecia Raul Bopp. José Ferreira de Souza e eu fomos morar com ele nos fundos de uma venda, em Olinda. Bopp foi uma bomba para mim. Ensinou-me a beber uísque. Ele foi a minha primeira grande amizade literária. José Lins do Rego

À convivência comigo - principalmente de 1923 a 1925 - José Lins do Rego atribuiu alteração profunda em sua vida.

\section{Gilberto Freyre}


literárias ${ }^{3}$ Já a segunda fase tem início com sua “conversão”, refletindo a duradoura "influência” do amigo pernambucano sobre sua vida e obra. José Lins chegaria mesmo a esboçar uma biografia do jovem Freyre, abarcando desde sua breve estadia em Minas até sua permanência em Maceió, a partir de 1926. Foi também nesta época que conviveu com Jorge de Lima e o grupo de escritores e intelectuais alagoanos, tais como Valdemar Cavalcanti, Aloysio Branco, Raul Lima, Aurélio Buarque de Holanda, Manuel Diegues Jr. Foi também nesse período que conheceu alguns daqueles que viriam a ser os grandes romancistas da década de 1930, caso de Rachel de Queiroz, Graciliano Ramos e Jorge Amado. O momento de crise propriamente dito, e de confessada e profunda transformação, José Lins identifica com sua volta de Recife à Paraíba, em 1924.

Interessa-me discutir em particular o significado que teve aquele momento de crise que se segue ao encontro do jovem paraibano com o novo amigo pernambucano e anglófilo. Para tanto, primeiramente procurarei traçar um esboço da biografia intelectual do aspirante a escritor, mapeando sua indecisa atividade jornalística durante a primeira juventude, particularmente os textos anteriores ao divisor de águas que teriam sido os anos 1923-24. Em seguida, identificarei alguns elementos que indicam uma radical transformação na trajetória do jovem escritor, ocorrida tanto em nível pessoal, como em seu projeto literário e político, ocorrência frequentemente atribuída à influência, ou melhor dizendo, ao encontro com o mestre recém-chegado da Europa e dos Estados Unidos ${ }^{4}$. Aproveitando, mas também recontextualizando o argumento introduzido por Moema Selma D-Andrea em seu $A$ tradição redescoberta ${ }^{5}$, sugiro finalmente que, ao identificar o significado

3 JLR também publicou textos no Colégio Diocesano quando era membro da associação literária Arcádia Pio X, entre eles um sobre o rei Alberto I da Bélgica (15/06/1915) e outro sob o título "Ave Polônia" (15/10/1916). Consta que teria ainda escrito um artigo sobre Joaquim Nabuco. Ver SODRÉ, Nelson Werneck. Orientações do pensamento brasileiro. Rio de Janeiro: Vecchi, 1942; e COUTINHO, Eduardo; BEZERRA DE CASTRO, Angela (Orgs.). Fortuna crítica. Rio de Janeiro/João Pessoa: Civilização Brasileira/Funesc, 1990.

4. Ao contrário de José Lins, a trajetória intelectual de Gilberto Freyre até os princípios dos anos 1920 é bastante conhecida nos dias atuais, tendo sido escrita e reescrita não só pelo próprio Freyre (que, como se sabe, costumava retocar e realçar dados de sua biografia), mas também por diversos biógrafos, muitas vezes tão mistificadores quanto o próprio biografado. O trabalho de Pallares-Burke indica alguns dos caminhos e descaminhos tomados por Freyre em sua temporada nos Estados Unidos e na Europa até antes da publicação de Casa grande e senzala, oferecendo elementos para uma melhor compreensão e, na verdade, para uma rigorosa reavaliação desta que é considerada uma das obras mais importantes do pensamento brasileiro. Cf. PALLARES-BURKE, Maria Lúcia Garcia. Gilberto Freyre: um vitoriano dos trópicos. São Paulo: Editora Unesp, 2005.

5 Cf. D'ANDREA, Moema Selma. A tradição redescoberta. 2. ed. revista e ampliada. Campinas: Editora Unicamp, 2010. 
adquirido por essa crise (que não é apenas uma crise da aristocracia rural), talvez possamos compreender melhor a formulação e o desenvolvimento de um certo regionalismo, praticado a partir e ao longo dos anos 1930.

\section{O cronista: entre decadente e panfletário}

Segundo os depoimentos de Freyre, foi a partir daquela crise pessoal e intelectual, decorrente do encontro entre ele e José Lins, em 1923, que o futuro escritor de Menino do engenho teria deixado a atividade de jornalista panfletário, provinciano ou afrancesado, para começar a sua verdadeira carreira literária. José Lins, por sua vez, sugere que seu encontro com o colega de geração estava quase predestinado, pois a atração por Freyre já existia desde os primeiros anos de sua adolescência. De acordo com o esboço de biografia que José Lins traçou do jovem amigo pernambucano por volta de 1927, Freyre teria dado uma palestra na Paraíba, quando este ainda tinha quinze anos de idade, intitulada "Spencer e o problema da educação no Brasil", à qual ele e Olívio Montenegro não teriam assistido, mas lido depois de publicada para, segundo ele, "nos compensarmos de umas nossas tolices da mesma

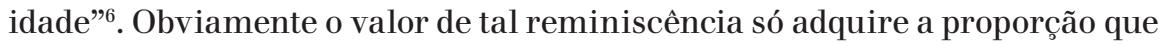
José Lins lhe quer atribuir porque é vista em retrospecto e em um contexto laudatório como o da biografia que ele então rascunhava. $\mathrm{O}$ que interessa aqui é compreender e avaliar não só a intensidade do impacto provocado por esse encontro, mas também o significado da transformação na postura intelectual de José Lins, supostamente ocorrida a partir desse momento. Para tanto, faz-se necessário conhecer um pouco mais as tentativas literárias e, como o próprio José Lins escreveria, suas "preocupações, leituras e entusiasmos" anteriores ao marco divisório a que se referem constantemente não só críticos, mas também os próprios protagonistas do encontro.

A primeira atividade profissional de José Lins corresponde mais ou menos ao período em que cursava a Faculdade de Direito do Recife, entre 1919 e $1923^{7}$. O futuro romancista começa a escrever artigos de jornal entre

6 MENESES, Diogo de Mello. Gilberto Freyre. Recife: Massangana/Fundação Joaquim Nabuco, 1991. p. 23. O autor publicou vários trechos dessa biografia, mas não revela onde estaria o manuscrito original. Segundo ele, a palestra teria sido em 1916: "Quase fugido de casa, lê na capital da Paraíba, no Cine-Teatro Pathé, a primeira conferência pública: 'Spencer e o problema da educação no Brasil', texto que teria sido publicado no jornal $\mathrm{O}$ Norte”. Pallares-Burke cita comentário de Freyre sobre essa palestra, registrado por ele em seu rascunho de autobiografia em inglès. Cf. PALLARES-BURKE. op. cit., p. 117 .

7 Os textos dessa época foram reunidos e publicados na antologia BRAGA-PINTO, César. Ligeiros traços: escritos de juventude de José Lins do Rego. Rio de Janeiro: José Olympio, 2007. 
janeiro e março de 1919 na coluna "Ligeiros traços", do jornal de oposição Diário do Estado da Paraíba, ao lado de José Américo de Almeida. Em artigo de 1922, José Lins do Rego comentava sobre o jornal e também sobre uma personalidade marcante que conhecera aos dezoito anos, durante uma conferência na Paraíba: "Um jornal de oposição é sempre pobre de tipos e rico de inteligências vigorosas. Era o que sucedia com o Diário do Estado. José Américo ganhava para todos os redatores do 'Diário': era o mais ouvido e quem falava menos... Escrevia ele todo o jornal" .

Dentre esses primeiros artigos, que ainda assinava como "José Lins do Rêgo", um dos mais conhecidos é sua defesa da candidatura de Rui Barbosa à presidência da República, a quem chama de "apóstolo sagrado" e "redentor da democracia", contra a de Epitácio Pessoa, candidato que viria a ser eleito ${ }^{9}$. Além desse e de outros artigos em que elogia Rui Barbosa, vale enfatizar, por exemplo, uma crônica na qual exalta Faria Neves Sobrinho, seu ex-professor e poeta parnasiano de Pernambuco ${ }^{10}$; ou o comentário sobre o filme Mistérios do Rio de Janeiro, adaptação para o cinema de uma novela do "incomparável escritor Coelho Neto" . Escritor contra quem poucos anos depois JLR escreveria severas críticas. De particular interesse para a obra ficcional do autor é "Morte de um trovador"12, artigo sobre a morte do negro José Passarinho, no qual JLR mais tarde se inspiraria para criar o personagem homônimo que aparece tanto no capítulo 32 de Menino de engenho, seu primeiro romance, de 1932, como em Fogo morto, de 1943, e sobre quem recorda: “...foi neste doido poeta de minha meninice onde eu encontrei o primeiro sentimento da poesia popular". Anteriormente, quando estudava sob o regime enérgico do colégio Pio X, escrevera também uma "Recordação feliz", em que expressa a saudade do engenho do avô, inspirada pela voz de uma "pregureira [sic] de pamonhas". Ali já se nota a veia memorialista e nostálgica do futuro escritor de Doidinho:

8 REGO, José Lins do. Reflexões de uma Cabra. Jornal do Recife, 18 jun. 1922. Ver também RABELLO, Adylla Rocha. Zé Américo e Zé Lins: os meninos de engenho se encontram. João Pessoa: FCJA, 1991; e ANDRADE, Ana Isabel de Souza Leão. Catálogo da correspondência de José Américo: cartas 1915-1952. João Pessoa: FCJA, 1983.

9 Ave Rui. Diário do Estado, 15 fev. 1919. O primeiro artigo de JLR nesse jornal é de 11 de janeiro de 1919. Segundo Nelson Werneck, há também notícia de um artigo de 1917, sobre Aluísio Azevedo, e um soneto intitulado "Ventura morta", que teriam sido publicados no mesmo jornal.

10 REGO, José Lins do. Um grande poeta. Diário do Estado, 24 jan. 1919. Gilberto Freyre escreverá sobre o último livro desse poeta no Diário de Pernambuco, em 26 de junho de 1923 .

11 Diário do Estado, 28 jan. 1919.

12 Diário do Estado, 23 fev. 1919. 
No vasto salão do velho e bem ordenado "Pio X", sob a presidência de Aprígio Fonseca, bizarra figura de Prefeito enérgico, eu na minha desmantelada banca de estudo com os olhos pregados nas páginas de uma Geografia, divagava imaginativamente pelas cidades formosas da Itália. ${ }^{13}$

No ano seguinte, o jovem estudante de Direito publica, em Recife, alguns poucos e pequenos artigos na revista Vida Moderna, assinados como "J.L. do Rego". Entre eles: "Princesa dolorosa"14, em que lamenta o exílio da Princesa Isabel "no seu rico e monótono castelo de França"; "Triste ocaso"15, no qual expressa sua compaixão pelo destino do então presidente americano Woodrow Wilson (que estava isolado depois de ter sofrido um derrame em outubro do ano anterior), um homem que "quis ser bom num século de maldades"; e "A erudição de um almofadinha"16, sua primeira narrativa de ficção, em que ironiza o que julga ser o artificialismo do conhecimento literário de um mulato - lugar-comum na literatura brasileira que o próprio Gilberto Freyre discutiria muitos anos mais tarde em seu Sobrados e mucambos.

Nessas primeiras crônicas já se pode identificar alguma preocupação política e literária, mas não há nenhuma posição definida, apenas uma ligeira indignação juvenil, um certo intimismo pós-romântico e, por vezes, um vago gosto pela cultura popular. É sobretudo entre o final de 1921 e o término de 1922 que "Lins do Rego" - como então passa a assinar - começa a se fixar como jornalista, contribuindo regularmente para a seção "Crônica social” e, mais tarde, para a primeira página do Jornal do Recife. Não é o caso de se esperar coerência ideológica ou um projeto estético definido do jovem de 21 anos naquelas primeiras tentativas literárias. Mas é possível identificar ali um certo desejo juvenil de compartilhar ideias com uma comunidade intelectual, ou, como um pouco mais tarde se explicitaria, de se sentir parte de uma geração de escritores. No entanto, a ideia de "novo" para o jovem José Lins do Rego ainda é bastante frágil, muitas vezes oscilando entre o entusiasmo e a reação. Encontram-se, dentre esses primeiros textos, crônicas de caráter simbolista, neoparnasiano ou penumbrista, como "Miss Fragilidade"17, em que não faltam doses de "languidez" ou "porcelanas orientais", além do legado de Anatole France, a que o autor mesmo alude em "Ceticismo francês". Nota-se também, aqui e ali, algumas crônicas mais prosaicas, como

13 Recordação feliz. Diário do Estado, 16 jan. 1919.

14. Vida Moderna, 8 mai. 1920.

15 Vida Moderna,17 jun. 1920.

16 Vida Moderna, 12 jun. 1920.

17 Jornal do Recife, 4 set. 1921. 
a simpática "Dr. Rotina"18; historietas bem ao gosto da Belle époque, que falam de bêbados e cocainômanos ${ }^{19}$; descrições em que se misturam referências ao pessimismo de Schopenhauer e a exuberância física do entrudo, como em "O último medieval”20 e descrições pós-simbolistas de pierrôs, misturadas com a fascinação pelos anarquistas Zé Pereiras e outras novidades do carnaval de 1922, período em que a festa de rua vinha tornando-se rapidamente popular e adquiria novas dimensões, com seus primeiros blocos e ranchos:

Sei que não gostas de versos, meu caro Zé Pereira, tu que és a negação à harmonia, à dor, ao espírito. Mas concordemos, amigos, apesar de não gostares de concordar em coisa nenhuma, concordemos que és a felicidade sem renúncia, a síntese barulhenta dos homens que perdem a linha, a expressão material de Dionísio sobre a terra, tu, Zé Pereira, “deus barulho" do "frevo"... !21

Ao lado dessas celebrações isoladas da alegria e das seduções dionisíacas, JLR começa também a ensaiar algumas críticas literárias e culturais. Em "Reflexões de uma cabra" 22 escreve sobre sua admiração pela obra do amigo José Américo de Almeida, que estava para publicar "seu primeiro estudo de costumes sertanejos": "É a vida originalíssima dos sertões que ele vai nos oferecer, encarnando um tipo, muito comum por lá, capaz do sacrifício até o abandono da personalidade" ${ }^{23}$. Em "O embaixador do paradoxo", publicada em 2 de julho de 1922, celebra o modernista português Antonio Ferro, ligado ao grupo da revista Orpheu (1915), que estava de passagem por Recife de onde seguiria para a Semana de Arte Moderna, em São Paulo. Nesse texto, José Lins aproveita para criticar o "nacionalismo epilético do

18 Jornal do Recife, 25 set. 1921.

19 Cf. REGO, José Lins do. Os que voltam à vida. Jornal do Recife, zo out. 1921 e Nevrose Branca, 12 mar. 1922.

20 Jornal do Recife, 5 mar. 1922.

21 REGO, José Lins do. Zé Pereira, Deus do barulho. Jornal do Recife, 26 fev. 1922. Do próprio José Lins, ver também "Um Lupp que eu vi", de 19 de fevereiro de 1922, e "O Homem que quis divertir o mundo", de 26 de março de 1922. Sobre o Zé Pereira, ver ARAÚJO, Rita de Cássia, Festas: máscaras do tempo, entrudo, mascarada e frevo no carnaval do Recife. Recife: Fundação de Cultura da Cidade, 1996; e RABELLO, Evandro. O carnaval da folia: o carnaval do Recife pelos olhos da imprensa. Recife: Funcultura, 2004. p. 18. JLR também escreverá mais tarde uma crônica intitulada "O frevo". Cf. Poesia e vida. Rio de Janeiro: Universal, 1945. p. 129.

22 Jornal do Recife, 18 jun. 1922.

23 Este livro de José Américo foi reeditado recentemente como Novelas (Boqueirão, Coiteiros e Reflexões de uma cabra). João Pessoa: Fundação Casa de José Américo, 1994. 
presidente Epitácio"24. Em "Epístola de um macróbio"25 dirige uma hostil carta aberta a Coelho Neto, em que clama: "Não há mais românticos, líricos e parnasianos: há escritores de ação pensando a toda hora. Isso seria duro para s.s. que nunca pensou em quase meio século de literatura". Em "Verdades a um lindo poeta" ${ }^{26}$ polemiza com Olegário Mariano, conhecido na época como "poeta das cigarras", associando mais uma vez mulatos ao decadentismo e artificialismo: "O Rio está cheio de poetas assim. São penumbristas, alguns mulatos de músculos de ferro a viver de abandonos, de outonos, a encontrar névoas no canal do mangue, e rimas calmas, de penumbras com brumas..." Curiosamente, tratam-se de críticas a que o próprio Lins do Rego, até pouco tempo antes, dificilmente escaparia. É importante lembrar também que o alvo do crítico é aquele mesmo poeta das cigarras a quem, em sua coluna "Ligeiros traços”, José Lins elogiara, em princípios de 1919: “Olegário Mariano é a quem eu devo a ressurreição de minha alma"27.

É somente em "Os novos" 28 que José Lins começa de fato a buscar e mapear a nova geração de escritores locais (entre eles Barbosa Lima Sobrinho, Múcio Leão ${ }^{29}$, Theo Filho e Lucilo Varejão), reclamando da decadência do ambiente intelectual em Pernambuco, que anteriormente girava em torno da Faculdade de Direito, e lamentando o fato de que todos os jovens de sua geração sonhavam em fugir para o Sul ${ }^{30}$. Em mais de uma crônica comenta o trabalho do dramaturgo carioca Renato Viana, de quem era grande admirador, comparando-o ao norueguês Henrik Ibsen ${ }^{31}$. Escreve também um de seus primeiros textos elogiosos sobre um poeta que mais tarde tanto

24. Segundo Neroaldo Pontes de Azevedo, Antonio Ferro fez duas conferências em Recife, em 12 e 14 de abril de 1923. Essa visita parece ter causado grande repercussão, com posições opostas entre si; Inojosa, por exemplo, escreve, a respeito, o artigo "Antonio Ferro, a hora presente" (A Rua, 11 abr. 1923); Tobias Jácome escreve "Antonio Ferro, embaixador da palhaçada" (O Fiau, 7 mai. 1923). Também Osório Borba comentou a visita, em "A arte de bem viver" (A Notícia, 18 abr. 1923). Cf.. Pontes de Azevedo. Modernismo e regionalismo: os anos 20 em Pernambuco. 2. ed. João Pessoa/Recife: UFPB/FUPE, 1996. p. 47-49.

25 Jornal do Recife, 6 ago. 1922.

26 Jornal do Recife, set. 1922.

27 Diário do Estado, 14 jan. 1919.

28 Jornal do Recife, 1 jan. 1922.

29 Segundo Gilberto Freyre, JLR teria escrito, em 1926, um ensaio crítico sobre Múcio Leão, que chegou a ser impresso, mas não publicado por conselho do amigo. Cf. FREYRE, Gilberto. José Lins do Rego e eu: qual dos dois influiu no outro? In: Alhos e bugalhos: ensaios sobre temas contraditórios, de Joyce a cachaça, de José Lins do Rego ao cartão-postal. Rio de Janeiro: Nova Fronteira, 1978. p. 47.

zo Uma versão desse texto seria publicada depois na revista carioca Arvore nova como "Os novos de Pernambuco", em outubro de 1922.

31 Cf. REGO, José Lins do. Um moralizador de teatro. Jornal do Recife, 24 de novembro de 1921; __. Uma noite de arte. Jornal do Recife, 15 dez. 1921; realidade. Jornal do Recife, 5 out. 1922. 
admiraria, e de quem seria amigo por muitos anos, dedicando-lhe mais de uma dezena e meia de artigos: o alagoano Jorge de Lima, aqui ainda em sua fase neoparnasiana, quando acabara de lançar o livro Comédia dos erros, reunião de ensaios de pretensões filosóficas e prosa de semitons regionalistas $^{32}$. José Lins reclama ainda da falta de intercâmbio entre os poetas do país, dizendo que "o Brasil é ignorado pelo Brasil", e critica a hegemonia cultural do Rio de Janeiro. Como exemplo a ser seguido, cita o caso de Raul Bopp, com quem, segundo depoimento posterior, teria morado nos fundos de uma venda em Olinda, durante o segundo ano de faculdade ${ }^{33}$. Já na época, José Lins escrevia sobre este que, segundo seu próprio depoimento, a cada ano cursava a faculdade de Direito numa capital diferente. Considerava-o sua "primeira amizade literária" e admirava seu papel aglutinador, agindo como uma espécie de embaixador cultural:

Pelo Recife passou em 1920 um poeta gaúcho dos mais interessantes que vi. Foi Raul Bopp, desbravando a Amazônia, arrebatado pela estética complicada das florestas, como dantes se reduzira pela civilização avançadíssima dos "Incas". Raul, de talento sutil, realizou a luta de uma maneira original. Vendo na mocidade um grande agente para as grandes ideias, fundou na Sé de Olinda, em cima daquela empolgante tradição poética e romântica, uma República de estudantes que liam Gauthieur e Anatole. E todos nós ficamos conhecendo toda a galeria artística dos "pampas", desde o príncipe boêmio de cetro de ouro, Zeferino Brasil, à juventude grega de André Carrazoni [...]. Além de tudo compôs ele conferências literárias sobre nossos homens, nossos aspectos e cores, para dizê-los no sul. ${ }^{34}$

Em outubro de 1922, José Lins ainda escrevia para o Jornal do Recife, que, conforme lembraria Gilberto Freyre, era um jornal "já em decadência" ${ }^{35}$. Nesse período, é a crise política local que cada vez mais consome sua atenção. O Jornal do Recife era considerado borbista, ou seja,

32 A comédia dos erros. Jornal do Recife, 19 mai. 1922.

33 Ver REGO, José Lins do. Foi a velha Totônia quem me ensinou a contar histórias. In: COUTINHO, Eduardo; BEZERRA DE CASTRO, Angela (Orgs.). op. cit., p. 62.

34 REGO. José Lins do. Intercâmbio intelectual. Jornal do Recife, 12 jan. 1922. É o próprio Bopp quem conta: "Como se sabe, fiz cada ano do curso de Direito em uma diferente Academia. Iniciei no Sul. Cursei o terceiro ano no Recife, o quarto em Belém do Pará, o quinto no Rio de Janeiro. Pude, dessa forma, conhecer um pouco o Brasil, especialmente o Norte". Cf. BOPP, Raul. Vida e morte da antropofagia. Rio de Janeiro: Civilização Brasileira, 1967. p. 11.

35 Cf. FREYRE, Gilberto. Em torno da Recifensização de José Lins do Rego. Ciência e trópico. Recife, v. 10, n. 2, p. 175-188, jul./dez., 1982. p. 180. 
ligado a Manuel Borba, que naquele momento apoiava a candidatura de José Henrique Carneiro da Cunha para governador (e Nilo Peçanha para presidente), contra a candidatura do ex-prefeito de Recife, Eduardo de Lima Castro, para governo do estado (e Artur Bernardes para o governo federal). Durante esse período, também escrevia para aquele mesmo jornal seu colega de faculdade, Joaquim Inojosa, futuro divulgador do modernismo paulista em Pernambuco, e que logo transferiu-se para o Jornal do Comércio, dos irmãos João e José Pessoa de Queiroz - da facção pessoísta/ castrista. José Lins acaba polemizando com Inojosa e responde aos ataques que julga serem de autoria do conterrâneo:

Você achou-me, pelo seu Jornal, órgão intelectual do "666", totalmente burro e cavador. Quanto a minha burrice, você a percebeu melhor do que eu. No entanto, lhe lamento a contradição. Ontem você era aquele homem de olhos lindos e sem cores, de feições híbridas a fazer artigos de crítica, achando-me com Austro [Costa] duas figuras novas do nosso momento intelectual.

Hoje sou burro e escrevo fantasias. Acredito, plenamente, na minha burrice, mas as fantasias deixo-as todas para você. É uma questão de direitos adquiridos. Isto quanto a minha burrice e as suas fantasias. Agora preciso dizer-lhe que não aspiro empregos públicos e nem tampouco tenho minha mocidade alimentada pelo estado. Meti-me nesta campanha em virtude duma dignidade coletiva... ${ }^{36}$

Tanto os borbistas da oposição, apoiados por José Lins do Rego, quanto os pessoístas-castristas da situação, então apoiados por Joaquim Inojosa e Gilberto Freyre, não deixavam de constituir facções da oligarquia local. Todavia, os borbistas, lançados pela chamada "reação republicana", estavam vinculados à tendência chamada "autonomista" (contra a intervenção federal) e tinham apoio de parte do proletariado e de alguns estudantes e professores da faculdade de Direito ${ }^{37}$. José Lins do Rego se

36 REGO, José Lins do. Essa carta ao Quincas. Jornal do Recife, 2 jun. 1922. A polêmica iniciara-se com artigo de José Lins contra Inojosa, que havia deixado o Jornal do Recife em 22 de junho de 1922, seguindo-se da réplica de Inojosa no Jornal o Commercio e em A Provincia em 23 mai. 1922, sendo que a "Carta" de JLR fora a tréplica. Inojosa ainda publicaria mais uma resposta no Jornal o Commercio, intitulada "Esta carta ao Zé Lins", em 4 de junho de 1922. Cf. PONTES DE AZEVEDO, Neroaldo. op. cit., p. 37.

Manuel Borba (1864-1928) havia sido governador de Pernambuco no período 1915-1919. Sobre JLR e a situação política dos dois grupos, ver: PONTES DE AZEVEDO, Neroaldo. op. cit., p. 26-zo, e REZENDE, Antônio Paulo. (Des)encantos modernos: histórias da cidade do Recife na década de 20. Recife: Fundarpe, 1997. p. 33-37. Ver também BORBA, Andréa. Manoel Borba: político de Pernambuco. Arrecifes, Recife, a. 2o, n.7, p.121-127, jul./dez. 1995 
vê cada vez mais engajado na querela política e, junto com Osório Borba, funda o jornal D. Casmurro, que, segundo Gilberto Freyre, era financiado por facção antipessoísta ${ }^{38}$.

Anos mais tarde, Osório Borba comentaria a origem daquela "revista doida varrida" e daquele "atormentado episódio de nossa juventude". Segundo ele, o jornal nascera "logo depois de uma campanha eleitoral que alagoanizara o Recife, com tiroteios quase diários, no centro e em alguns bairros, com a cidade cheia de jagunços vindos do interior, instalados em sobrados da rua Nova e da rua do Imperador, escaramuçando com a polícia

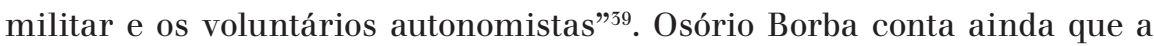
revista começou a ser impressa na gráfica de $A$ Noite, de Nelson Firmo, com tiragem de dois mil exemplares, "imitando o sistema de manchetes que não se conhecia no Recife". Segundo ele, José Lins, "naturalizado pernambucano como acontece a todos os nordestinos que chegam ao Recife", teria participado de campanha eleitoral a favor do candidato autonomista e rosista ${ }^{40}$ (o "usineiro" José Henrique Carneiro da Cunha) e adversário dos epitacistas, representados pelo ex-prefeito de Recife (o "opulento comerciante" Eduardo de Lima Castro). Conforme seu depoimento, o jovem paraibano fora orador apaixonado, deixando lembranças para os colegas que assistiam a ele, "gritando anátemas contra os 'cangaceiros paraibanos', aos matutos glacialmente indiferentes" ${ }^{41}$. O jornalista conta ainda que a ideia da D. Casmurro surgiu logo depois de ele ter publicado, sob o pseudônimo S. Pererê, "um livrinho satírico sobre a figura de opereta de um ex-governador interino" (Severino Marques Pinheiro), com o título de "Na corte de dom Bio Zero". O panfleto teria contado com um prefácio de JLR, que assinou então Artur Minuz, "adulteração de um senador e membro da academia pernambucana" (i.e., Arthur Muniz).

No editorial do primeiro número de D. Casmurro informa-se ao leitor tratar-se de uma publicação de cunho assumidamente panfletário, enfatizando:

contra os moldes comuns da imprensa ultra-conservadora, cuja falsa doutrina de moderação oculta, muitas vezes, uma orientação

e SILVA, Jorge Fernandes da. Vidas que não morrem. Recife: Secretaria de Educação. Departamento de Cultura, 1982. p. zoz-zo6.

38 Cf. FREYRE, Gilberto. Em torno da Recifensização de José Lins do Rego. op. cit., p. 80.

39 Tribuna da Imprensa, 27 e 28 set. 1957.

40 Rosa e Silva foi o grande oligarca pernambucano, vencedor nas eleições para governador em 1911, mas deposto por Dantas Barreto.

41 Gilberto Freyre também comenta: "Antes falara de improviso nos comícios dos chamados 'autonomistas' de Pernambuco; gastara-se na mais estéril e vã das retóricas demagógicas". Cf. FREYRE, Gilberto. Alhos e bugalhos. op. cit., p. 49 . 
de acomodatismo, de alheamento à vida ambiente, de inércia egoística... Procurará refletir o movimento das ideias de hoje, com a divulgação do pensamento novo que uma geração de elite elabora na obscuridade dos meios nortistas, forçando a inércia e a indiferença provincianas. ${ }^{42}$

Durante os seis meses de sua publicação, o semanário parece ter alcançado alguma visibilidade entre a juventude da época ${ }^{43}$. Dentre os colaboradores anunciados pelo jornal, vale enfatizar a participação o professor da Faculdade de Direito Joaquim Pimenta (1886-1963), figura central do borbismo, líder dos trabalhadores e fundador do jornal Diário do Povo, em 13 de setembro de 1921, e que inspiraria a criação de Joaquim Pestana, um dos personagens de relevo do romance $O$ moleque Ricardo, de 1935. Segundo notícia publicada no D. Casmurro, Pimenta era "um pensador de ideias novas, um doutrinador sereno de multidões. Entre os professores de nossa decadente Academia, ele pode muito bem ser chamado o seu espírito novo" ${ }^{44}$.

Dentre os artigos de cunho político - nenhum deles assinado por José Lins do Rego - encontra-se também alguma crítica literária como, por exemplo, a resenha do livro Horizonte, de Oliveira e Silva, em que o autor já começa a se opor ao modernismo paulista, manifestando ainda sua assumida simpatia pelo parnasianismo:

livro de pensamento amadurecido, de serenidade emocional, em que o lirismo parnasiano esplende, brilhante e claro, como a melhor resposta às extravagâncias infantis que a geração dos futuristas de São Paulo tenta agora mesmo erigir em doutrina de reação contra a estética parnasiana. ${ }^{45}$

Já o segundo número de D. Casmurro, datado de novembro de 1922, traz um conhecido artigo de José Lins sobre Lima Barreto, escrito por ocasião de sua morte, no qual se lê uma frase de Lima Barreto que se

$42 \quad$ D. Casmurro, 1 nov. 1922.

43 A revista foi publicada entre 1/11/1922 e 16/04/1923, tendo atingido pelo menos 25 números. A quantidade varia entre 25 e 30 , segundo a fonte. O Arquivo do Estado de Pernambuco tem os números 1-3, publicados em novembro de 1922, e 17-18, de fevereiro de 1923 . Segundo Luiz do Nascimento, a Coleção de Oséas Borba teria outros números. Em 15/oz/1923, no jornal $A$ Noite, de Nelson Firmo, comenta-se o final da publicação (Ver Luiz do Nascimento, v. 3, 217-218).

44 D. Casmurro, 6 nov.1922.

45 OLIVEIRA E SILVA. O pensamento brasileiro na voz das novas gerações. $D$. Casmurro, n. 1 . 
tornaria célebre e orgulhosamente lembrada por José Lins muitos anos mais tarde como expressão de sua própria estética modernista-regionalista: "Os grandes escritores têm a sua língua. Os medíocres, a sua gramática" ${ }^{46}$. Elogiará ainda, em artigos da época, os lançamentos dos então respeitados poetas Silva Lobato ("Frauta de Pan") ${ }^{47}$ e Austro-Costa ("Mulheres e rosas"). Durante esse período, José Lins colabora também com a revista Arvore nova, dos espiritualistas cariocas, com o artigo "Os novos de Pernambuco" (out. 1922), com elogios derramados a Laurindo Leão e Joaquim Pimenta e, mais uma vez, escreve sobre Austro-Costa, que considera "o mais poeta de todos", "poeta doido que é quase meu irmão".

A afiliação de José Lins ao grupo da revista carioca Arvore nova e sua crítica ao modernismo paulista antecedem seu encontro com Freyre, estando ainda presente no artigo intitulado "Enquanto os futuristas de S. Paulo fazem ridículos, uma geração no Rio salva a cultura brasileira”. O autor condena a virada de Guilherme de Almeida para o "futurismo" e critica os outros "reacionários da capital" da revista Klaxon ${ }^{48}$. O texto de D. Casmurro faz elogios a Tasso da Silveira e a Rocha de Andrade, os fundadores da revista que, segundo o autor, ofereceriam "uma nova descoberta do Brasil ao Brasil”. Nesse texto ecoa aquela postura anterior sobre Raul Bopp, mas também prefigura alguns aspectos do regionalismo tradicionalista mais tarde atribuído a Gilberto Freyre ${ }^{49}$. Enfim, a autonomia estética defendida por D. Casmurro

46 Ver outro artigo sobre Lima Barreto, reproduzido em Poesia e vida (p. 69), no qual o próprio JLR afirma: "Quando ele morreu em 1922, ainda adolescente, escrevia em Recife: 'Os grandes escritores têm a sua língua. Os medíocres, a sua gramática”.

47 Austro-Costa era o pseudônimo de Austriclínio Ferreira Quirino (1899-1932).

48 Artigo reproduzido em PONTES DE AZEVEDO, Neroaldo. op. cit., p. 195-196.

49 Vale lembrar que a revista Arvore nova era dirigida por Rocha de Andrade e Tasso da Silveira (1895-1968), o mesmo que anteriormente fundara, junto com Andrade Muricy e Jackson de Figueiredo, a América Latina: revista de arte e pensamento. Publicada entre julho de 1919 e fevereiro de 1920, essa revista se declarava "órgão de defesa do espírito latino-americano"; mais tarde, ao lado de Álvaro Pinto, Tasso da Silveira dirige Terra do sol: revista de arte e pensamento (jan.-mar. de 1924), que conta com as colaborações de, entre outros, Jackson de Figueiredo e Tristão de Athaíde; e, mais tarde, com Andrade Muricy, a Revista festa: mensário de pensamento e arte, em que colaboravam vários dos mesmos poetas e prosadores. Em carta de 6 de junho de 1924 a JLR, GF comenta artigo do amigo sobre a Faculdade de Direito, que teria sido publicado na Terra do sol. O título leva a crer que deva ser o mesmo publicado alguns dias depois na Era nova (Algumas notas sobre a faculdade de Direito do Recife. Era nova, ano IV, n. 64, 15 jun. 1924). Em um de seus artigos numerados, Freyre escreve que teria sido JLR a divulgar a revista Terra do sol no Recife (Diário de Pernambuco, “45”, 24 fev. 1924). De fato, um dos números da revista enumera seus representantes espalhados em todo o Brasil, dentre os quais constam, em Pernambuco, José Lins do Rego (Recife) e Mário Sette (Olinda). Todas essas revistas são marcadas por seu caráter pós-simbolista, espiritualista e arielista (o mestre Nestor Victor era chamado de "o Rodó brasileiro"), e tinham em seu núcleo o mesmo 
não deixava de estar vinculada à defesa de uma suposta autonomia política dos seus editores ${ }^{50}$.

\section{Assim renasce uma geração: os filhos de senhores de engenho}

Mais do que ninguém é Freyre quem frequentemente insistirá em dizer que o período em que conviveram em Recife (na verdade, pouco mais de um ano) teria determinado a “conversão" de José Lins de jornalista panfletário a verdadeiro escritor. E, com alguma dose de maldade, chega a lembrar que, quando os dois se conheceram, o amigo paraibano estava "escrevendo melhor que qualquer outro, artigos violentos contra os nós das gravatas de Estácio Coimbra, contra os sapatos de baile de Sérgio Loreto, ou contra a barba fidalga de Pedro Paranhos, dos quais se acabaria tão amigo" ${ }^{51}$. Freyre comenta ainda que um amigo do governador - que naquele momento estava para oferecer-lhe o cargo de diretor da Biblioteca do Estado - o teria advertido contra a amizade com o jovem jornalista. Entretanto, segundo ele, isso não o impediria de se aproximar daquele "rapaz perdido"52. Vale a pena reproduzir o trecho, cheio de malícia ferina, mas nem por isso menos saboroso, do depoimento de Freyre:

Panfletariamente contra o Governador interino Severino Pinheiro, contra o Governador Sérgio Loreto, contra o genro do Governador e Diretor de Saúde Pública, o brilhante Amaury de Medeiros, contra

grupo de escritores católicos, mais ou menos ortodoxos, além da contribuição dos jovens Manuel Bandeira, Cecília Meireles, Sérgio Buarque de Holanda e Jorge de Lima.

5o Para melhor se compreender o cenário político em Pernambuco nesta época, cf. SILVA, Jorge Fernandes da. op.cit., p. 201-205 e Almanaque de Pernambuco, Recife, 1924. p. 253-255; FREYRE, Gilberto. Estácio Coimbra, homem representativo do seu meio e do seu tempo; conferências promovidas pelo Instituto Joaquim Nabuco de Pesquisas Sociais em novembro de 1972 por ocasião do centenário do nascimento do ilustre brasileiro, e proferidas por Gilberto Freyre et al. Recife: Instituto Joaquim Nabuco de Pesquisas Sociais, 1973, p. 24. PORTO, José da Costa. Os tempos de Estácio Coimbra. In: Os tempos da república velha. Recife: Fundarpe - Diretoria de Assuntos Culturais, 1986. Amaury de Medeiros era genro de Sérgio Loreto e tomou posse como diretor do Departamento de Saúde Pública e Assistència em 1923. Gilberto Freyre era seu grande admirador e refere-se a ele em alguns de seus artigos da época: O "9" da série numerada do Diário de Pernambuco (17 jun. 1923); o "14" (23 jul. 1923); o "19" (26 ago. 1923).

51 Cf. FREYRE, Gilberto. Alhos e bugalhos. op. cit., p. 48.

$5^{2}$ Segundo Nelson Werneck Sodré, Freyre não teria sido nomeado para o cargo de diretor porque, depois de uma visita aos hospitais do Recife com Amauri de Medeiros, teria escrito um artigo "incisivo e contendo uma análise imparcial", quando a administração pernambucana esperava "elogio apaixonado e indiscutível”. Cf. SODRÉ, Nelson Werneck. Orientações do pensamento brasileiro. Rio de Janeiro: Vecchi, 1942. p. $5^{1 .}$ 
Estácio Coimbra, então ainda vice-presidente da República, de quem José Lins do Rego, aproximando-se por meu intermédio, se tornaria admirador e contra quem escrevera enfaticamente, quando Dom Casmurro a serviço de grupo partidário hostil ao mesmo Estácio. Dom Casmurro era financiado por esse grupo, do qual secretamente fazia parte o aliás simpático Barão de Suassuna. Contou-me José Lins vir uma vez pela Rua Nova com o Barão a seu lado. De repente, surgiu um amigo de Estácio. E o Barão, em voz baixa, ao jovem panfletário: “finja que não vem comigo". Com o que o panfletário sentiu-se humilhado. Era como - contou-me ele - se o repúdio do Barão fosse o de um Barão de Laivos por jovem de requebros suspeitos com quem não devesse ser surpreendido. ${ }^{53}$

Barão de Laivos, como se sabe, é o protagonista do romance homônimo de Abel Botelho, de 1891, que conta a história de um relacionamento homossexual entre um homem casado e um rapaz muito mais jovem. Outros comentários sobre a má companhia do jovem boêmio e "raparigueiro" eram, segundo Freyre, comuns entre os "alarmistas" e "moralistas" da época: "Um talento esse rapaz com quem você anda, esse sobrinho do Leitão, mas um perdido. Vive se embebedando com cerveja nas pensões de Santo Amaro e dando escândalos com raparigas"54.

Ao que tudo indica, Gilberto Freyre deve ter testemunhado apenas o período final da publicação de D. Casmurro, pois retorna da Europa em 8 março, e o panfleto de JLR e Osório Borba foi empastelado em 16 de abril de 1923, quando as oficinas foram invadidas e destruídas pelas autoridades governamentais ${ }^{55}$. Naquele mesmo ano, depois de associar-se à chamada Arte Moderna (divulgada em Recife por Joaquim Inojosa), Austro-Costa, que anteriormente fora objeto de elogios por parte do jovem jornalista paraibano, publica no jornal A pilhéria um poema jocoso, de sua autoria,

53 Cf. FREYRE, Gilberto. Em torno da recifensização de José Lins do Rego. op. cit., p. 180.

54. Cf. FREYRE, Gilberto. Alhos e bugalhos. op. cit., p. 43.

55 A correspondência entre Freyre e JLR começa em maio de 1924, um ano e um mês depois do fim de D. Casmurro. A primeira carta de JLR é datada de 14 de abril de 1924. Em Cartas de Gilberto Freyre (João Pessoa: Funesc, 1997. p. 29) os autores mencionam a carta datada de 17 de janeiro de 1924. Observam que nela comenta-se a morte de Antonio Sardinha, que veio a falecer um ano depois, em janeiro de 1925, e concluem, corretamente: "deve ter havido, portanto, um equívoco de GF ao escrever a data”. De fato, a carta só pode ser de 1925, já que em janeiro de 1924. José Lins ainda estava em Recife. Trata-se de uma bela carta em que Freyre se recorda da viagem que havia feito anteriormente à Paraíba: "Tenho às vezes muitas saudades de você. Há horas em que estou só e o apito do trem de Limoeiro, do outro lado do morro, me faz pensar muito em você”. 
em que ridiculariza a Freyre e a macaqueação de seu companheiro paraibano:

(Ao Freyre com Ypsilon):

Se você, gingando, passa

Da irônica populaça

Por entre o sorriso anônimo

O Lins também sai gingando

Entre dentes exclamando

-Mestre! Meu mestre e pseudônimo ${ }^{56}$

Com o fim da revista, e sua aproximação da figura todo-poderosa de Gilberto Freyre, José Lins do Rego parece ter primeiramente perdido o rumo e, ao se ver tomado de grandes inseguranças, começa a reavaliar suas ambições literárias, assim como suas posições ideológicas ${ }^{57}$. Tendo terminado o curso de Direito, resolve voltar logo à Paraíba para se isolar no engenho de seu avô. Durante esse período é que se delineia o cerne da narrativa da "conversão" de José Lins do Rego que, para Freyre, foi "parecida com a de Santo Agostinho"58. Tal conversão, segundo Freyre, dar-se-ia na forma de "superação de um provinciano rural por um recifense" e, ao mesmo tempo, revalorização de suas "origens telúricas..."59 "Dando-lhe uma nova pele cultural sobre a carne do bom provinciano cru... Novos olhos. Novos ouvidos. Novo paladar. Novo alcance sexual. Novos gostos..."60

Tal reviravolta na vida do rapaz provinciano está vinculada também a um reposicionamento religioso, além de uma radical mudança comportamental. Depois de formado, e já de volta à Paraíba, em abril de 1924, JLR escreverá alguns artigos esparsos para a publicação local Era nova: revista quinzenal ilustrada, na qual contribuíram também José Américo de Almeida, Coelho Neto, Olívio Montenegro, Joaquim Inojosa, Monteiro Lobato, Lucilo

56 A pilheria, 8 set. 1923, apud. PONTES DE AZEVEDO, Neroaldo. op. cit., p. 131.

57 GF não chegou a acompanhar os artigos de JLR no Jornal do Recife. Mas segundo ele, JLR the teria passado um caderno com retalhos de jornais contendo os artigos escritos na época cf. FREYRE, Gilberto. Alhos e bugalhos. op. cit., p. 49. Da Paraíba, JLR escreve a JF: "Eu preciso, sobretudo, da reação interior que em mim é ainda um ensaio com muitas probabilidades de fracasso (1924); “Tenho em mim grande descrédito pelo que escrevo. Acredite que estou sendo sincero. Sempre que me leio acho que podia fazer melhor. $O$ pior é que este melhor nunca consigo.” (15/07/ 1924).

58 Idem, ibidem, p. 49.

59 Cf. Idem, Em torno da recifensização de José Lins do Rego. op. cit., p. 182.

6o Idem, ibidem, p. 178. 
Varejão, Jorge de Lima e o próprio Freyre ${ }^{61}$. A chave para a compreensão desse período de transformação na trajetória do escritor paraibano, inclusive a relação com o "novo" que então se delinearia, pode estar justamente nesse desejo de pertença. Essa nova identidade, sentida ou imaginada, seria expressa em um artigo fundamental, publicado em setembro de 1924 na revista Era nova, intitulado "Carta de uma geração aos srs. Gilberto Freyre e Jackson de Figueiredo". Todavia, antes de analisar o conteúdo da carta aberta e situar a nova direção tomada por José Lins do Rego, é necessário compreender o contexto em que foi publicada ${ }^{62}$.

Segundo seu depoimento a Francisco de Assis Barbosa, José Lins do Rego escrevera durante esse período seu primeiro livro, cujo título era Reflexões em torno de um livro, com prefácio de Gilberto Freyre, onde este qualifica o trabalho do amigo discípulo de, apesar de "desordenado", uma obra que "encanta pelo movimento e pelo frescor de juventude inquieta" ${ }^{63}$. O prefácio não chegou a ser concluído, mas termina com as seguintes palavras:

[...] A mim me parece que o ensaio do meu amigo, como todo o seu desordenado, dá pleno direito ao Sr. Lins do Rego a figurar entre os mais jovens desse moderno e brilhante grupo de agitadores de idéias: O "Brasil Novo" do senhor Tasso da Silveira. Aliás, o próprio Sr. Tasso da Silveira chamou-o uma vez: "homem do Brasil novo".

Eu não tenho a superstição do novo e até me deixo gostosamente acusar do contrário. Confesso, porém, uma ingenuidade: a de supor que a geração ainda verde dos mais moços que o século, os que o choque da guerra pegou meninos, aguçando-lhes a sensibilidade e o senso de valores, pressagia um Brasil superior ao atual - a essa geração podre de madura de que só se salvam os au dessus de la mêlée ${ }^{64}$. Poderíamos talvez repetir, os da geração a emergir, aquelas palavras de Peguy: "Nous ne savons pas si nous serons hereux, mais nous ne savons que nous ne serons pas petits". É-nos, neste sentido, favorável a violen... $[\text { sic }]^{65}$

61 A revista Era nova foi publicada entre 1921 e 1925.

62 Este texto de José Lins do Rego é discutido na segunda parte da já citada obra de Moema Selma de D'Andrea. Acredito que a contextualização que se propõe aqui oferece uma visão mais sutil da trajetória do escritor paraibano, levando em conta contradições (pessoais e políticas) que de certo modo permanecerão vivas nas suas obras de ficção.

63 Cf. COUTINHO, Eduardo; BEZERRA DE CASTRO, Angela (Orgs.). op. cit., p. $6 z$.

64. "Au dessus de la mêlée" é o título do célebre artigo de Romain Rolland, publicado em em um jornal suíço em 1914, contra a guerra. Cf. ROLLAND, Romain. Au-dessus de la mêlée. Paris : A l'Emancipatrice, 1915 .

65 Idem, ibidem, p. 64-65. 
Como se viu, o próprio José Lins vinha tentando encontrar o "Brasil Novo" nessa identidade de grupo, definindo afinidades e recusando determinadas associações. Por outro lado, Freyre parece ter dado seu aval para que o amigo participasse de certa elite intelectual e, mais importante, de uma geração, desbravadora e "mais jovem do que o século". O conteúdo e também muitas palavras do manuscrito - inclusive a citação de Péguy - reaparecem na célebre conferência "Apologia pro generatione sua", pronunciada na Paraíba no início de abril de 1924, em que Freyre exalta os jovens de sua geração a se reintegrarem à tradição e ao espírito de ordem de seus antepassados ${ }^{66}$. O livro de José Lins nunca seria publicado, mas provavelmente uma parte dele é o que está no artigo da Era nova, "Apontamentos sobre um livro de ensaios II", sobre Múcio Leão, publicado dois meses depois da conferência de Freyre, em $1^{\circ}$ de junho de 1924. José Lins polemiza com Múcio Leão para atacar Ernest Renan e, ao mesmo tempo, exaltar Ernest Psichari, escritor francês cuja obra lhe fora recentemente apresentada por Freyre.

Grande parte da conferência de Freyre discute a vida e obra do escritor francês Ernest Psichari ${ }^{67}$ (1883-1914) - neto de Ernest Renan (1823-1892), uma das figuras intelectuais de maior destaque do século XIX na França. Anticlerical

66 FREYRE, Gilberto. Apologia pro generatione sua. Parahyba, 5 abr. 1924. Palestra realizada no Theatro Santa Rosa na Parahyba a 5 de abril de 1924, e mandada publicar pela commissão de intellectuaes sob cujos auspicios esteve Gilberto Freyre na Parahyba: Carlos D. Fernandes, Álvaro de Carvalho, José Américo de Almeida, Guilherme da Silveira, Matheus de Oliveira, Celso Mariz, Adhemar Vidal, Antenor Navarro e Padre Pedro Anisio Bezerra Dantas. (A palestra foi modificada e depois reproduzida em FREYRE, Gilberto. Região e tradição. Rio de Janeiro: José Olympio, 1941). Em carta de 16 de junho de 1924, Freyre comenta: "Sobre a conferência, acabo de receber um cartão de Antenor: ninguém mais desejoso que o caso da conferência tenha uma solução definitiva, de preferència a publicação, do que eu. Mas não posso transigir nos pontos alegados. Papel feio não serve. Por favor explique à boa amizade do Antenor minhas caturrices em certo ponto". O texto citado aqui é o reproduzido na Biblioteca Virtual Gilberto Freyre (Disponível em: http://bvgf.fgf.org.br. Acesso em: 3 jan. 2011). Sobre a conferência e a viagem de GF à Paraíba, ver também REGO, José Lins do. Gordos e magros. Rio de Janeiro: Casa do Estudante do Brasil, 1942. p. 123-125. Em seu Um vitoriano nos trópicos, Maria Lúcia Pallares-Burke discute o contexto dessa conferência-manifesto e conta que foi logo traduzida para o inglês por Francis Simkings que, mais tarde, diria que ali "Freyre renega a filosofia urbana de seu pai em favor da 'fé agrária de seu avô do engenho"”. Cf. PALLARES-BURKE. op. cit., p. 232.

67 Escreveu, entre outros, L'appel des armes (1913) e Levoyage du centurion (1915). A primeira foi a mais influente de suas obras. A biblioteca pessoal de JLR contém a segunda, mas as páginas do livro não foram recortadas, o que indica que provavelmente JLR não o leu. Sobre sua vida e obra, ver FIELD, Frank. British and French Writers of the First World War. Cambridge U. Press, 1991 e também NEAU-DUFOUR, Frédéric. Ernest Psichari: l'ordre et l'errance. Paris: Du Cerf, 2001, em que o autor faz um retrato de Psichari um tanto diferente do ortodoxo admirado por Freyre. Segundo o autor da biografia mais recente, Psichari continuou a admirar os princípios do avô e criticou com frequência o comporta- 
e republicano, Renan tornou-se o grande teórico da nação e autor do polêmico A vida de Jesus (1863). Suas Cartas íntimas seriam anos depois (em 1946) traduzidas para o português pelo próprio Osório Borba, o amigo de juventude de JLR. Já Psichari viveu em ambiente de intenso liberalismo intelectual, antirracista e anticlerical. Além de ser neto de Renan por parte de mãe, era filho do filólogo grego Jean Psichari, fundador da Liga dos Direitos Humanos no momento do affaire Dreyfus. Foi amigo de Jacques Maritain (1882-1973) e discípulo do nacionalista e "anti-Dreyfusard" Maurice Barrès. A princípio cético, Psichari acabou por se alistar no exército e se converteu ao cristianismo durante uma missão na África, tendo morrido em combate em 1914, no início da Primeira Grande Guerra. Seu mais influente livro, L'appel des armes (1913), trata da história de um jovem que se revolta contra os valores antimilitaristas e anticlericais de seu pai. Depois de se alistar no exército colonial, aprende que o exército está acima da nação, representando suas forças eternas, e não seus contingentes históricos. Assim, para o personagem do romance (e provavelmente para Psichari) a maior descoberta de um jovem é que a guerra é divina. A relação entre neto e avô, representada pela figura de Psichari, é central para a definição de geração no texto de Freyre e, como se verá, também para José Lins do Rego.

A conferência de Freyre define "espírito" ou "consciência” de geração como "uma forma de patriotismo", constituída em termos de "destinos comuns" e "deveres de lealdade recíproca". Esse sentimento abstrato de lealdade assume particular importância naquele momento em que os jovens em questão eram os da geração do pós-guerra: "Ao falar dum Rupert Brooke, dum Otto Braun, dum Ernesto Psichari tenho a impressão de falar de compatriotas. Eles fundaram com o sangue a pátria que é a geração dos que hoje somos os homens de vinte e de trinta anos". Assim, Freyre elege alguns daqueles que representariam esse espírito da geração pós-guerra, destacando, no caso do Brasil, o nome de Jackson de Figueiredo ${ }^{68}$. A primeira metade do texto trata de Randolph Bourne (1886-1918) que, segundo Freyre, teria sido espelhado no personagem de Jean Christophe, protagonista da série de romances em dez volumes de Romain Rolland, publicada entre 1904-1908. Como tantos outros jovens

mento dos franceses nas colônias. Além disso, sua conhecida homossexualidade estaria muito longe dos preceitos católicos mais ortodoxos.

O ensaio publicado em Região e tradição (1941) está bastante alterado em relação à conferência de abril de 1924. Inclusive Freyre elimina alguns nomes que considera como "Jean Christophes inquietos". A seguinte passagem, por exemplo, já não aparece: "nos Estados Unidos, em Randolph Bourne e Wan Wick Brook; na Inglaterra, em Rupert Brooke; na França, em Peguy, em Psichari, em Jacques Maritain; na Itália, em Giovanni Papini; em Portugal, em Fidelino de Figuerêdo e Antonio Sardinha; no Brasil, em Jackson de Figuerêdo". 
intelectuais da época, também José Lins lia a obra de Rolland e admirava a formação espiritual do artista em Jean Christophe, conforme se vê em carta ao amigo: "Eu descobri muito de você em Jean Christophe". Freyre, por sua vez, responde: "Nas suas impressões de Jean Christophe achei um sabor pessoal delicioso: J. Christophe é isso mesmo. É um romance de aventuras da alma." (16/06/1924).

Já a segunda parte da conferência de Freyre é um elogio a Ernest Psichari que, segundo ele, é quem melhor definiria o que entendia por "patriotismo de geração". Uma espécie de comunidade constituída por meio de afinidades transnacionais:

Em Ernesto [Psichari o que venho chamando] o patriotismo de geração teve quase o rubro ardor dum coração de Jesus, ardendo [misticamente] e sangrando da volupia do sacrificio. Ennesto Psiehari, que será talvez um dia Santo da Igreja, já tem para nós, seus irmãos mais moȩos, os d'après-guerre, a ala reeem ehegada de forȩas jovens, alguma eousa de Santo. Ninguém, a não ser Peguy, teve tão clara a consciência dos destinos de sua geração: "tout se joue sur nos têtes". ${ }^{69}$

O modelo que Freyre identifica em Psichari é o de uma relação específica entre um jovem e seus pais, ou entre as novas gerações e as gerações que imediatamente as precederam. Interessa-lhe o que chama de: "inversões de papéis sociais: reacionários [tradicionalistas] os filhos diante dos pais neófilos"70. Segundo Freyre, o romance L'appel des armes de Psichari seria o melhor exemplo desse paradoxo em que o velho se torna novo e o novo se torna velho. Em outras palavras, o ensaísta procura justificar situações em que os filhos defendem a tradição, contrariando os pais que, ao contrário, defendem a novidade. Para ser realmente rebelde em relação aos pais, o melhor seria o jovem se unir àqueles contra quem seus pais se rebelaram, ou seja, aos avós; e Freyre cita Psichari:

“Nós é que somos os pais dos nossos pais" é a conclusão paradoxal a que chega Ernesto na sua reacção contra duas gerações de desgarrados da continuidade histórica [francesa e católica], e nossos pais

69 FREYRE, Gilberto. Apologia pro generatione sua. op. cit., p. 9o. A título de comparação, cito com rasuras os textos excluídos na versão publicada em Região e tradição e os adicionados entre colchetes.

70 Idem. Região e tradição. op. cit., p. 9o. Importante notar a mudança de "reacionário", termo que remete ao conservadorismo católico de Jackson de Figueiredo, para "tradicionalista”, termo mais alinhado ao projeto Freyreano posterior. 
são péssimos filhos. ..."C'est nous qui sommes leurs pères. Et ils sont de bien mauvais fils..."

Para Freyre, Psichari, apesar de sua ascendência multiétnica, desenvolveu, ao contrário do que era de se esperar, "um senso de ordem e ânsia de fixidez"; ou seja, uma reintegração à linhagem interrompida pelos pais. $\mathrm{O}$ escritor francês é admirado, sobretudo, por sua reconversão ao Cristianismo, depois de um breve desvio. Reintegração que se dera por meio do estudo disciplinado da história e da vida dos antepassados. Além disso, depois de Psichari ter-se deixado encantar pelo socialismo, pelo marxismo, pelo antimilitarismo e pelo "dreyfusismo", teria finalmente encontrado sua vocação de soldado, que o levaria à "conversão" definitiva: "A vida de soldado vai aprofundar-lhe o senso de ordem; vai aguçar-lhe o espírito ou consciência de geração; vai acelerar-lhe o ritmo da vida interior". A conversão de Psichari, que se dá depois de três anos de silêncio, em sua segunda viagem à África, é descrita por Freyre em termos inequivocamente bíblicos:

Ele e a paisagem vão agir um sobre o outro. Percorrendo a doee [vagaroso] passo de camelo,sobosolforte, o areal desolado, Ernesto põe-se em contacto com os ́ntimos valores morais [mais intensos] da terra e da paisagem; e ao côro das vozes que clamam no deserto começa a conversão do neto de Renan [ao catolicismo e à tradição francesa; sua volta à continuidade histórica]. ${ }^{71}$

Pode parecer paradoxal que, para Freyre, Psichari se tivesse rebelado não só contra o pai, mas também contra Renan, seu avô: "que o avô Renan quebrara um dia em mil e um pedaços o crucifixo da família; e veio o neto e o recompôs"72. E que Freyre afirme que "pela influência do pai, o Professor Jean Psichari, foi Ernesto desenvolvendo nos estudos o senso de ordem que lhe faltara”. Mas, para se entender a lógica enviesada de

71 Idem, ibidem, p. 94 .

72 A imagem será lembrada, ainda em 1931, por Valdemar Cavalcanti no editorial-manifesto do primeiro número da revista alagoana Novidade, para a qual o próprio JLR viria a colaborar: "A nossa [geração] tem um destino a cumprir: vencer primeiramente os erros da outra e passar adiante; como no programa de Psichari, apurar os defeitos e as virtudes de nossos pais, buscando no exemplo do passado aquelas como que marcas de passos que dizia ser dever dos bons pais deixarem pela vida para orientar os filhos. E - aproveitando a imagem admirável dum ensaísta brasileiro - juntar, pedaço a pedaço, os restos do crucifixo quebrado pelo avô Renan.” Novidade, 11 abr. 1931, apud. SANT'ANA, Moacir Medeiros. História do modernismo em Alagoas (1922-1932). Maceió: UFAL, 1978. p. 203. Devo essa referência a Ieda Lebensztayn, cuja recém-publicada tese de doutorado trata da revista alagoana. Cf. LEBENSZTAYN, Ieda. Graciliano Ramos e a Novidade: o astrônomo do inferno e os meninos impossíveis. São Paulo: Hedra, 2010. 
Freyre, é necessário aceitar que o verdadeiro "pai” espiritual nesse caso é o avô Renan, a quem Ernest Psichari sucede diretamente, já que a marca de seu pai era a "neutralidade":

Assim, pela inteligêneia inteligentemente dominada pelo ritmo interior da alma, voltou Ermesto Psieharià ordem de que saira o avô, pela orgia da mesma inteligeneia... De fato, um Ernesto, passada uma geração, corrigiu o outro. Completou-o. Retificou-o... E por toda a parte o programa de pensamento e ação da mocidade é hoje um programa de retificação [Ou melhor, de compensação. Processo de todas as épocas, talvez: as gerações sempre se compensam. Mas processo particularmente intenso em nossa época]. No Brasil, é preciso que retifiquemos os falsos valores de que há cinquenta anos vivemos, reintegrando-nos no Brasil brasileiro dos nossos avós... ${ }^{73}$ Felizmente, da nova geraȩão brasileira strgem esboesos de "leaders" e sombras de profetas [reação em que se têm salientado pensadores e críticos como]: Agripino Grieco, Oliveira Vianna, Jackson de Figueirêdo, Antonio Torres, Gilberto Amado, Ronald de Carvalho, Renato Almeida, Tristão de Athayde, Perillo Gomes, Andrade Muricy e Tasso da Silveira [irmãos mais velhos da nossa geração]. ${ }^{74}$

José Lins estava presente na conferência, ao lado de intelectuais como José Américo e Adhemar Vidal. Naquele momento, familiarizava-se com a obra do escritor francês por sugestão de seu amigo e mentor ${ }^{75}$, como se pode verificar em carta sua enviada a GF: "Comecei a ler Psichari. E encontrei nele o que você me disse dele"76. Já de volta à Paraíba, o jovem escritor escreve para a revista Era nova o artigo "Apontamentos sobre um livro de ensaios"77, agora com sua assinatura de "convertido", como queria Freyre. O texto de José Lins do Rego foi publicado em princípios de junho, dois meses depois da

73 Na versão revisada, Freyre desenvolve esta última frase: "Também à geração nova do Brasil se impõe uma série de retificações, de reintegrações e de compensações, em relação com excessos dos antecessores. Talvez o nosso esforço tenha de ser apenas de indagação e de interpretação [...]”. FREYRE, Gilberto. Região e tradição. op. cit., p. 97. Idem, ibidem, p. 97 .

75 Mais tarde JLR escreveria: "Lembro-me de seus artigos sobre Psichari, o outro Ernesto, como ele o chamava no Natal de 1924". REGO, José Lins do. Gordos e magros. op. cit., p. 124 .

76 FREYRE, Gilberto. Alhos e bugalhos. op. cit., p. 42.

77 Apontamentos sobre um livro de ensaios II. Era nova, n. 63, ano IV, 1 jun. 1924. Não parece existir uma primeira parte deste artigo, pelo menos na Era nova. O artigo é na verdade sobre Mucio Leão que, segundo JLR, "ainda acredita em Renan com olhos fechados" (1916). Mais tarde, em Alhos e bugalhos, GF se refere à publicação como uma "revistazinha literária da Paraíba chamada pomposamente Era nova" (p. 47). 
conferência de Freyre. E nele o autor já se refere a Psichari, ao mesmo tempo em que critica a "incredulidade perversa" de Renan ${ }^{78}$. A alusão é quase um resumo da conferência de Freyre: "Em 28 de fevereiro de 1924, centenário de Renan, Barrès falou oficialmente de Renan. Falou-lhe de seu mestre para exaltar-lhe os netos: - Ernest e Michel Psichari que vieram salvar o avô tão doente". Este texto de JLR adquire um significado ainda maior quando se sabe que, menos de um mês antes, morria-lhe o avô. Na ocasião, Freyre lhe escrevera: "Boa figura de senhor de engenho deve ter sido aquele seu avô. Eu não sei qual é o gosto de ter um avô" (29/06/1924) ${ }^{79}$. O desejo de reatar com a tradição e o passado do avô se manifesta logo em seguida, em setembro daquele mesmo ano, quando José Lins confidencia ao amigo: "Para o ano serei finalmente senhor de engenho". (30/10/ 1924).

Com a leitura de Psichari e de outros católicos franceses, José Lins distancia-se da figura que dominou a atenção de grande parte da intelectualidade nacional nas primeiras décadas do século XX: "Outro recurso maior do Sr. Múcio é Anatole France. Recurso que o jovem ensaísta procura para tudo e em todos os casos. Ora, Anatole tem o seu limite. Escritor sóbrio, bom estimulante, com muitas cores, serve-nos como um bom automóvel para um passeio". Desse automóvel seriam passageiros muitos brasileiros, como lembra uma contemporânea de José Lins, muitos anos mais tarde, em 1935: "De uns anos a esta parte tem diminuído sensivelmente entre nós a influência da cultura francesa. Pode-se dizer que Anatole France foi o último escritor francês a imprimir o seu cunho a uma geração" ${ }^{80}$.

José Lins ainda escreveria pelo menos dois artigos antes de, em setembro daquele mesmo ano de 1924, escrever a "Carta" na qual continuará a definir suas afinidades e a revelar os pontos fundamentais daquilo que se tornaria a narrativa de sua "conversão": "Algumas notas sobre a faculdade de Direito do Recife" e "A Paraíba e seus problemas" último, JLR compara o silêncio de José Américo de Almeida ao do próprio Psichari, ao mesmo tempo em que alude aos "romances porcos de Aluísio de Azevedo" e ao "maracatu verbal de Cruz e Souza"; além de citar Castro Alves, que, segundo ele, "se gastou em apiedar-se de negros robustos que estavam tão bem nos servindo na escravidão". O assunto principal do texto é o recém-publicado livro de José Américo, sobre quem afirma: “O

78 Apontamentos sobre um livro de ensaios II. Era nova, n. 63, ano IV, 1 jun. 1924 .

79 Em Alhos e bugalhos, Gilberto Freyre comenta a carta de 14/06/1924, tarjada de preto, "porque lhe acabara de morrer aquele avô senhor de engenho" (op. cit., p. 46).

80 Cf. Pereira, Lúcia Miguel. A leitora e seus personagens. Ed. Luciana Viégas. 2. ed., Rio de Janeiro: Graphia/Fundação Biblioteca Nacional, 2005. p. 116.

81 Publicados em Era nova, 15 jun. 1924 e 15 jul. 1924, respectivamente. 
que mais me espantou, porém, no sr. José Américo de Almeida foi o seu ponto de vista de reacionário que ele sustentou para os de sua geração”. Sobre esse texto Freyre logo comentaria em uma de suas cartas ao amigo: "Li (e foi um grande gozo a leitura) o seu artigo sobre o livro de José de Almeida. Dá bem a idéia de sua situação: da transição que v. vai atravessando, sem prejuízo das forças de seu temperamento." (14/08/1924).

Voltemos agora ao texto de José Lins, intitulado "Carta de uma geração aos srs. Gilberto Freyre e Jackson de Figueiredo”. No periódico, este vinha acompanhado de uma ilustração, legendada "Após a descida da cruz", e começava agradecendo aos dois escritores do título o fato de terem mostrado um novo "espírito de ordem” à sua geração: “Não podíamos compreender mocidade sem tumulto, sem reflexão, sem desordem". JLR culpa os pais, ou seja, a geração anterior, que lhes oferecera como principal fonte de inspiração o cientificismo e as obras de Zola, Taine, Spencer, e, mais uma vez, critica Renan: "E assim fomos feitos homens, para pensar e agir. Homens que não careciam e nem temiam a Deus". Condena, acima de tudo, a influência de Rui Barbosa, "um homem que amamos loucamente": "Porque a todos nós que íamos atrás de seus discursos nada nos dera ele para nos refazer. Deixou-nos com a sua morte os mesmos: os que iam ao senado ouvir o demagogo". Culpa ainda o liberalismo, o positivismo e o cientificismo, além do perigo do "militarismo". E, finalmente, lamenta o que chama de "falta de vida interior" do exército.

O ensaio de José Lins aponta uma nova direção para a constituição do pensamento de todo um grupo de jovens intelectuais. Nele, além de Freyre, o pensamento católico e conservador de Jackson de Figueiredo adquire importância fundamental. Segundo Moema Selma D’Andrea, “um no Rio, outro no Recife, pregam o espírito da 'ordem' e da ‘ortodoxia', prestando o apoio intelectual às medidas repressoras dos governos Epitácio Pessoa e Arthur Bernardes" ".2. Assumidamente reacionário, Jackson de Figueiredo vinha publicando, pelo menos desde 1921, n'O Jornal, do Rio de Janeiro, textos em que se declarava católico e "inimigo da revolução". Os primeiros desses textos estão reunidos em seu A reação do bom senso: contra o demagogismo e a anarquia militar, em cujo prefácio o autor afirma em tom de protesto:

Os resultados aí estão. É a política transformando o soldado de fator da disciplina em bandeirante de desordem... é enfim o Brasil desta campanha presidencial, de que saímos, e em que horas houve em que não ficou de pé um só talvez dos pontos de honra da vida política

82 D'ANDREA, Moema Selma. op. cit., p. 97. 
e social de um povo o mais modesta ou elementarmente civilizado, no sentido cristão desta palavra... ${ }^{83}$

Nos anos seguintes, Jackson de Figueiredo publicaria ainda uma série de textos, reunidos em Literatura reacionária (1924) e A coluna de fogo (1925), cujo impacto sobre seus contemporâneos talvez ainda não tenha recebido a devida atenção da crítica e historiografia intelectual brasileira. O texto de José Lins parece referir-se especificamente ao artigo "Hoje como Hontem", publicado em 9 de julho de 1924 n'O Jornal e reproduzido na coletânea de 1925 . Nesse artigo, Jackson de Figueiredo declara sua posição em relação ao movimento dos tenentes em São Paulo, que culminou na rebelião do dia 5 de julho, exatamente dois anos depois do levante do Forte de Copacabana no Rio de Janeiro. Em seu texto, Jackson de Figueiredo exalta o soldado como encarnação de "um princípio de disciplina social" e afirma que "já não se pode considerar soldado aquele que nega a disciplina militar, a hierarquia dos órgãos do Estado, a vontade da Nação" ${ }^{84}$. Finalmente, condena a ação dos tenentes em São Paulo:

O novo crime aí está. S. Paulo, a formosa, a admirável cidade de indústria, de comércio, de arte, orgulho mais legítimo talvez do coração brasileiro, lá está a arder, a debater-se sob a metralha dos mesmos revoltosos, dos mesmos soldados indisciplinados, dos mesmos inimigos do exército, que há dois anos bombardearam a capital da república... ${ }^{85}$

Freyre, por sua vez, imediatamente reagiria de forma bastante parecida, publicando naquele mesmo mês de setembro o artigo "Em torno da revolta" ${ }^{86}$. O tom é o mesmo de Jackson de Figueiredo, mas Freyre parece também associar a revolução estética paulista, deflagrada no mesmo ano da revolta do Forte de Copacabana, com a indisciplina política e militar:

83 FIGUEIREDO, Jackson de. A reação do bom senso: contra o demagogismo e a anarquia militar. Artigos publicados n'O Jornal, do Rio de Janeiro, 1921-1922. Rio de Janeiro: Anuário do Brasil, 1922. p. 25.

84 Idem. A coluna de fogo (7/24-7/25). Rio de Janeiro: Anuário do Brasil, 1925. p. 24.

85 Idem, ibidem, p. 27.

86 O artigo vem assinado apenas com "G.”, mas não há dúvida de que seja de autoria de Gilberto Freyre. 
As recentes revoltas - a d'agora e a de 1922 - vêm, entretanto, acentuar a necessidade dum mais vivo espírito de disciplina e dum mais forte senso de ordem. A nós, os novos homens do Brasil, toca a missão de reintegrar o Brasil nas suas tradições de ordem... [As forças vivas do país] colocaram-se a favor das tradições de ordem contra esse delírio de "futurismo" político, a um tempo ridículo e perigoso. ${ }^{87}$

Ao que tudo indica, a situação política no Sudeste do país ocupava bastante a atenção dos intelectuais conservadores como Freyre que, no calor da hora, escreve uma carta a José Lins, lamentando: "Parece-me um tanto sombria a situação no sul. Leu minha nota sobre a revolta? Parece que perderam de todo o senso de ordem. Diabo de liberalismo e diabo de infinito de rebelião! A revolução é por certo um direito extremo: porém nunca um direito de militares. Nunca" (14/07/1924). Também José Lins não deixaria de se manifestar a respeito e, em carta de agosto de 1924, escreve ao amigo: "Escrevi para a Era Nova uma carta dirigida a você e a Jackson de Figueiredo, das atitudes que vocês tomaram sobre o movimento de São Paulo".

Assim como para Freyre, também para José Lins o debate político se associa ao debate estético, sobretudo no que diz respeito ao modernismo paulista que naquele momento se difundia pelo Brasil. $\mathrm{O}$ movimento foi divulgado em Pernambuco graças à ação de Joaquim Inojosa, que, depois de sua curta experiência com a revista Mauricéia (de novembro de 1923 a janeiro de 1924), receberia um convite para se tornar colaborador da revista Era nova, a mesma para a qual José Lins começava a escrever. No dia 5 de julho de 1924, Inojosa aceita o convite, escrevendo diretamente aos diretores da revista uma longa e polêmica carta que logo viria a ser publicada em separata como "A arte moderna: carta literária dirigida a Severino de Lucena e S. Guimarães Sobrinho, diretores da revista Era nova da Paraíba do Norte”. Trata-se de um texto, com intenções de manifesto, em que Inojosa chamava a atenção para as repercussões do movimento literário do Sul em outras partes do país, inclusive em Pernambuco, e clamava aos paraibanos que aderissem ao movimento. A carta, como se sabe, alcançaria grande repercussão, incitando respostas e críticas das mais diversas personagens intelectuais do país, tais como José Américo de Almeida, Mário de Andrade e Oswald de Andrade, entre vários outros ${ }^{88}$.

87 FREYRE, Gilberto. Em torno da revolta. Diário de Pernambuco, 9 jul. 1924, publicado também em $O$ Semeador, de Maceió, 10 jul. 1924.

88 Cf. INOJOSA, Joaquim. A arte moderna:6o anos de um manifesto. Rio de Janeiro: Cátedra, 1984. Ver também PONTES DE AZEVEDO, Neroaldo. op. cit., p. 61-72 e REZENDE, Antonio Paulo. op. cit., p. 171-178. 
Um dos objetivos centrais da "Carta” de José Lins do Rego era firmar uma nova posição política e estética, contrária à que havia tomado anteriormente, associando-se agora a um novo pensamento e a uma nova parcela de sua geração. Segundo o autor, foram Gilberto Freyre e Jackson de Figueiredo, com suas posições cristãs e tradicionalistas, que forçaram esta nova geração a um exame de consciência e a concluir que:

[...] afinal de contas, o nosso único destino é o destino de homens rurais. Não somos nem militaristas, nem positivistas, nem democratas, nem futuristas. Somos senhores de engenho, fazendeiros e católicos apostólicos romanos. Fugindo daí estamos de braços com a anarquia, porque fugimos de nossa verdadeira vocação. ${ }^{89}$

Poucos meses depois do empastelamento de seu jornal panfletário D. Casmurro, José Lins agora defendia Epitácio Pessoa e o governo de Artur Bernardes; ao mesmo tempo em que criticava a retórica de Nilo Peçanha, condenava as rebeliões populares e, sobretudo, as dos militares, classe que, segundo ele, finalmente começava a ser reintegrada à imagem daquilo que o soldado "deve ser". E a imagem do soldado que JLR tem em mente é, precisamente, a de Psichari: "O soldado francês sabe amar e sentir, com um encanto especial, o seu métier. Sabe sentir que por ele a França começou a retornar ao seu histórico espírito de ordem, que uma filosofia de motins arrasara". Enfim, em sua opinião, o que faltava para o exército brasileiro era "vida interior": "Não é que se queira um exército de literatos, nem de sociólogos. Apenas um exército de verdadeiros soldados. Soldados sobretudo. Um erro de educação fez de uma grande parte de nosso exército um erro de desordem, porque lhe deram posições que antes devia ele garantir que dominar". José Lins conclui dizendo que, ao condenar o que se passava naquele momento em São Paulo, Gilberto Freyre e Jackson de Figueiredo introduziram à nova geração o desejo de, com eles, "refazer o Brasil".

O texto de JLR é uma resposta a Freyre em vários sentidos e a sua intenção central é revelar uma nova convicção: a de que é necessário acima de tudo valorizar a tradição e a ordem como fundamento da nacionalidade brasileira. Tal espírito de ordem José Lins defenderá agora com toda convicção. Não é à toa que, justamente nesse período (mais especificamente no dia 21 de setembro), o até recentemente boêmio e "raparigueiro" estudante de direito resolve mudar de estilo de vida e se casar, confessando ao

89 REGO, José Lins do. Carta de uma geração aos srs. Gilberto Freyre e Jackson de Figueiredo. apud D’ANDREA, Moema Selma. op. cit., p. 104. 
amigo que o fizera "mais por necessidade de ordem que de coração" (carta de 30 de setembro de 1924). Mais uma vez, a palavra "ordem", usada no âmbito privado, corresponde a um contexto político e estético brasileiro específico, além de remeter à obra de Psichari e de Jackson de Figueiredo, fundador do jornal $A$ Ordem. Ao lado da profunda transformação na vida pessoal, José Lins se preocupa também com a manutenção da ordem social estabelecida e com o perigo representado pelas revoltas do tenentismo (e do "futurismo") em São Paulo.

Gilberto Freyre logo responderia à carta aberta que o amigo lhe dedicara na revista paraibana. A princípio em correspondência particular, em que simplesmente comenta: "Vi a Era nova. Um interessante artigo, o seu, passeando sobre o assunto com sapato de sola de borracha." (1/10/1924). Em seguida, publicaria um comentário em sua coluna de artigos numerados no Diário de Pernambuco, congratulando a ortodoxia defendida por José Lins do Rego: "ortodoxia que para Ernest Psichari foi mais que romance de ideias: foi vida vivida". E acrescenta: "vede nossos homens, os maduros, os de quarenta, cinquenta, sessenta anos... Espírito de subserviência não lhes falta, ao grande número. Mas espírito de ordem não possui nenhum: são eles - muitos à meia luz, é certo - os inimigos da tradição, os 'revoltosos', os 'comunistas', os 'futuristas" ".90. Freyre lamenta que os lugares onde se carece mais de ortodoxia no Brasil sejam justamente "a igreja, a Faculdade de Direito e o exército". E conclui: “A nós, os mais novos, nada de mais romântico se oferece hoje, que a defesa da ortodoxia. Os velhos desdenham-na: defendamo-la os moços. E há um heroísmo na defesa, maior, às vezes, que no ataque". No final da década, já em Maceió, José Lins ainda comentaria sobre aquele antigo mestre dos jovens reacionários católicos, recentemente (e precocemente) falecido: "Não escrevia para vencer na vida, escrevia para vencer a vida" [...] "Para o Sr. Jackson de Figueiredo o Evangelho tem sido mais um incentivo à luta que um conselho a contemporizações"91. Finalmente, enfatizaria também o papel do catolicismo na elaboração de um pensamento tradicionalista e, logo, regionalista: "O pensamento da Igreja quer fazer do passado mais uma contribuição, ou como diria Mauras, um 'capital transmi'. A sua sabedoria está em não tornar este capital num simples amontoado, e sim num patrimônio vivo, sempre a se movimentar, a descobrir novos meios de aquisição"92.

Levaria ainda quase uma década entre o encontro com Freyre e a publicação de seu primeiro romance, mas os dilemas pessoais, políticos e

90 FREYRE, Gilberto. 8o. Diário de Pernambuco, 26 out. 1924.

91 REGO, José Lins do. Uma revista de pensamento. Jornal de Alagoas, 1 mai. 1929.

92 Idem. Do bom tradicionalismo, Jornal de Alagoas, 13 abr. 1927. 
religiosos (que, acredito, não se dever reduzir somente ao "estado de crise" da aristocracia rural) evidentes nesses princípios dos anos 1920, e a marcada orientação tradicionalista - quiçá conservadora ou mesmo reacionária que seu pensamento assumiu naquele momento, sem dúvida alimentaram toda sua carreira de memorialista. Muito ainda haveria de acontecer e muito tinha José Lins para aprender (e ensinar) durante a década que se segue, antes de se tornar um dos grandes romancistas da década de 1930. Em Maceió, assumiria ele mesmo o papel de líder intelectual, de certo modo emulando, no âmbito da província alagoana, o papel (em certos aspectos modernizador e crítico do provincianismo mais estreito) representado por Gilberto Freyre em sua primeira juventude no Recife. Ao isolar os primórdios desse diálogo nitidamente transformador e dessa amizade duradoura e quase lendária entre Freyre e José Lins, o que interessa não é simplesmente condenar ou cristalizar uma imagem dos dois escritores em suas tendências mais retrógradas. O trajeto que liga o jovem escritor boêmio e panfletário ao pensador católico e, bem mais tarde, ao romancista moderno, é certamente sinuoso e complexo, e não se presta a uma simples retificação. Do mesmo modo que a relação entre o Freyre das grandes obras de interpretação do Brasil escritas nos anos trinta, aparentemente isolado entre dois momentos notoriamente conservadores, não se explica e não se justifica facilmente. Em ambos os casos torna-se fundamental atentar com todo o cuidado a certas afinidades, frequentemente subestimadas, como aquela entre a produção dos dois escritores aqui estudados e o pensamento católico do grupo carioca, desfazendo-se assim qualquer divisão nítida entre uma corrente simbolista-espiritualista e os chamados regionalistas. Apenas assim poderemos compreender o verdadeiro sentido adquirido por aquele apelo à ordem, cujas origens europeias estão essencialmente no trauma vivido pela guerra e na ameaça representada pelo movimento desestabilizador das vanguardas, mas que no Brasil assume características muito próprias. No caso específico de José Lins, em cuja produção ficcional a memória desempenha um papel central, torna-se ainda fundamental comparar-se os diversos momentos e os diferentes registros narrativos (o do testemunho confessional, o do cronista e finalmente o da ficção memorialística) para que se compreenda como configurou-se uma literatura que veio a ser entendida como "do nordeste", sobretudo nesta sua vertente em que a tradição é revalorizada e, de certo modo, reinventada. Enfim, tal releitura não deve resolver as contradições, seja de uma personalidade muitas vezes hesitante, como pareceu ser a de José Lins do Rego, seja de uma época em que a cultura literária assume um papel notoriamente ambíguo, ao mesmo tempo crítico e conivente, que nem sempre soube distinguir o popular do populista, muitas vezes confundindo o apelo à ordem com revolução. 